\title{
Civilizing pirates: Nineteenth century British ideas about piracy, race and civilization in the Malay Archipelago*
}

\author{
Stefan Eklöf Amirell
}

\section{Introduction}

Piracy has long been a prominent topic among historians of the Malay Archipelago, and the numerous studies that have been published over the last half-century have resulted in a substantial corpus of knowledge, both about the phenomena of piracy and maritime raiding in the region as such, and about the efforts of colonial powers to suppress such activities, particularly during the nineteenth century (e.g. Tarling 1978 [1963]; Rubin 1974; Trocki 2012 [1979]; Warren 1981, 2002; Teitler et al. 2005; Eklöf Amirell 2019, forthcoming).

One of the main conclusions that emerge from these studies is that there was often a close connection between the suppression of piracy and the extension of colonial territory. Nineteenth-century proponents of colonial expansion often found that allegations of piracy worked well as a pretext for military and political intervention in autonomous Asian states, and that such claims generally carried more moral weight among sceptical governments and residents of the imperial metropole than economic or geopolitical arguments for colonial expansion. The presumptive need to suppress piracy around the world (particularly in parts of Asia and Northern Africa) was thus often used to promote aggressive imperialist policies while serving, more or less successfully, to mask their underlying and generally more pragmatic and self-interested intent.

One aspect that to date has not been systematically investigated, however, is the link which nineteenth-century European actors and observers saw between piracy and civilization, particularly the notion that piracy and maritime raiding in the Malay Archipelago could be explained by the perpetrators' alleged lack of civilization. Against this background, the purpose of the present article is to highlight the ways in which British colonizers from the $1810 \mathrm{~s}$ until the $1880 \mathrm{~s}$, as well as their opponents, sought to understand the historical and cultural reasons for the prevalence of piracy and related forms of maritime raiding in the Malay world, particularly with regard to notions of civilization and progress on the part of allegedly inferior or semi-civilized 'races', such as the Malays. In spite of considerable inconsistency and heterogeneity, such notions had profound consequences both for the development of British colonial policy in the region and for the rise of anti-imperialist opinion and criticism of colonisation in Britain.

\footnotetext{
* Research for this article was funded by a project grant from the Swedish Foundation for Humanities and Social Sciences (Riksbankens Jubileumsfond). I want to thank Bruce Buchan, Griffith University, for valuable comments and suggestions, and John Hennessey, Linnaeus University, for careful editing and language review.
} 


\section{Civilization and the suppression of piracy}

The word 'civilization' is of relatively recent origin, emerging in Europe only in the eighteenth century. Its root is the older word 'civil', derived in turn from the classical Latin civilis, meaning 'relating to the citizen', which by the early modern era had taken on the meaning in French and other European languages of 'courteous' or 'polite'. The idea of civilization, as it developed in French from the mid-eighteenth century, and shortly afterwards in English and other European languages, was thus generically normative (Fisch 1992: 684-92; cf. Elias 1939). The term civilization was part of a dichotomy of so-called asymmetric counter-concepts, as theorized by Reinhard Koselleck (1985), made up of a superior concept which, in order to be meaningful, required an inferior counterpart. The inferior counterpart to civilization was 'barbarism', 'rudeness' or 'savagery'. The latter terms were associated with a wide range of cultural practices and values on the part of nonEuropeans which Europeans tended to regard as repulsive or abominable.

The idea of civilization and its asymmetric counterparts contained a strong evolutionary element, as the history of mankind, according to the dominant historicist paradigm, seemed to involve a general movement from the savage or barbarian to ever higher stages of civilization. European civilization was seen as the most advanced, with other nations having developed various degrees of civilization, either autochthonously or through contact with more advanced peoples. Some nations - or 'races' in the vocabulary of the Victorians - also seemed, for various reasons, to have degenerated from formerly higher stages of civilization to contemporary lower levels.

As European economic, military and political superiority over the rest of the world increased in the course of the nineteenth century, this stadial view of history manifested itself in the notion that Europeans had a special obligation to spread their civilization to other people. This was the idea of the so-called civilizing mission, that is, "the self-proclaimed right and duty to propagate and actively introduce one's own norms and institutions to other peoples and societies, based upon a firm conviction of the inherent superiority and higher legitimacy of one's own collective way of life", as put by Jürgen Osterhammel (2007: 14).

The development of the ideas of civilization and the civilizing mission largely coincided with a shift in focus for the European efforts to suppress piracy around the world. Before the mid-eighteenth century the pirates who were of most concern to the European authorities and trading companies were European renegades operating on the fringes of the major colonial empires, where naval presence and government authority was weak, such as in the Caribbean and the Indian Ocean. ${ }^{1}$ These pirates - the 'enemies of all', as Cicero had famously called them - were to be chased and exterminated regardless of where in the world they were operating, and from the beginning of the eighteenth century the British began to take a leading role in the efforts to suppress piracy around the world. As a result, by 1730, piracy had become all but extinct, at least when it came to the mainly European freebooters who in the previous decades had ravaged parts of the major sea lanes between Europe and the Americas and between Europe and India (Earle 2004; cf. Rediker 2004).

\footnotetext{
1 In addition, the Barbary corsairs caused some problems for European shipping in the Mediterranean, and occasionally beyond, from the 1570 s to the 1830 s. It was not clear to early modern Europeans, however, that Barbary corsairs were pirates as they operated, at least nominally, under the licence of a recognized sovereign, viz. the Ottoman Emperor; see further Kaiser \& Calafat 2014; White 2018.
} 
The suppression of European piracy, however, did not mean that the concept of piracy had outlived its usefulness, although it did change in its meaning and function. In 1784, the British Parliament passed the East India Company Act, which aimed to bring the Company's rule over India more firmly under its control. The Act, among other things, limited the authority of the presidencies subordinate to the governor-general in India (whose jurisdiction included Southeast Asia) to make war or negotiate treaties with foreign rulers. The legislation thus limited the scope of action for the Company's officials in Sumatra and the Strait of Malacca, leading them to seek a legal loophole around the new restrictions. Incidentally, maritime raiding emanating from the Sulu Archipelago in the southern Philippines was rapidly increasing at the time, mainly as a result of the increasing demand for slaves needed for the production of export commodities from the Sulu Archipelago to China (Warren 1981, 2002). Against this background, allegations of piracy provided British colonial officials in the region with a pretext for military intervention when deemed necessary, without having to seek permission from their superiors in London or Calcutta. Local officials also believed that it was necessary for the British to demonstrate their control of the major sea lanes and not confine themselves to defensive measures in order to guarantee the free flow of commerce in the region (Rubin 1998: 222).

Toward the end of the eighteenth century the increasingly frequent clashes between alleged pirates and colonial authorities in Asia combined with the influence of stadial theory to create an understanding in Europe of contemporary piracy as associated mainly with less civilized non-European groups of people. Then major piratical nations of the world seemed to be the maritime Malays and certain Arab tribes, particularly the inhabitants of the so-called Barbary states of North Africa and the Al Qasimi of the so-called Pirate Coast of the southeastern Persian Gulf. The propensity to engage in piracy came to be seen as a collective, racial or cultural, trait on the part of certain nations or 'races', rather than as a form of individual delinquency or act of subversion among certain morally reproachable individuals of European nationality (Eklöf Amirell 2019, forthcoming; cf. Layton 2011).

Against this background, the suppression of piracy around the world became not only a pretext for colonization and a sine qua non for free trade; it also became a moral imperative for the European powers to extend the boundaries of civilization by eliminating the remaining pockets of piracy in the world, particularly after the end of the Napoleonic Wars.

\section{"We may look forward to an early abolition of piracy"}

The foremost British authority on the Malay Archipelago in the early nineteenth century was Sir Thomas Stamford Raffles, who served as Lieutenant-Governor of Java during the British occupation of the island between 1811 and 1815 and as Lieutenant-Governor of Bencoolen on the west coast of Sumatra from 1817 to 1822 . His extensive writings on the history and culture of the region, including his monumental History of Java (1817), formed the basis for much of the subsequent British policies in Southeast Asia, not least with regard to piracy and its suppression.

Raffles' explanations for the prevalence of Malay piracy were not entirely consistent and they changed, as we shall see, over time (cf. Reber 1966). Up until around 1817, his main line of argument was that piracy was an ancient evil and an intrinsic part of Malay culture, as 
supposedly demonstrated by the pride with which piracy was spoken of in old romances and fragments of traditional history (Raffles 1817: 232). In a speech before the Society of Arts and Sciences in Batavia in 1813 he compared the contemporary situation in the Archipelago, (with the exception of the more advanced civilization of Java), with that which prevailed in early ancient Greece. In both cases the numerous and thickly scattered small islands made sea travel the only viable means of communication, and in both cases the innumerable islands and ports offered outstanding opportunities for piracy. The early Greeks, much like the contemporary Malays, were in a "barbarous state" and their society plagued by "perpetual marauding and piratical warfare", according to Raffles. The opportunities for plunder offered by the Phoenician trade and other interests in the Aegean Archipelago, moreover, turned piracy into a long-standing honourable practice among the Greeks (Raffles 1830: 180).

Apart from the geography and uncivilized state of the Malays, a further cause of piracy among the Malays, according to Raffles, was the "intolerant spirit of the religion of Islam". Arab religious teachers, he claimed, never neglected to enforce the merit of plundering and massacring the infidels, particularly the non-Muslim tribes of the Eastern Islands. This "abominable tenet", according to Raffles, had more than all the rest of the Koran contributed to the propagation of this "robber-religion" among the Malays. The result was that the practice of piracy now is "an evil too extensive and formidable to be cured by reasoning, and must, at all events, be put down by the strong hand" (Raffles 1830: 78). ${ }^{2}$

In 1819, on the other hand, Raffles seemed to have abandoned cultural and religious explanations for piracy. Instead, he now argued that it was the ruthless and monopolistic commercial policy adopted by the Dutch over the past 200 years which was responsible for the general decline and impoverishment of the indigenous Malay states. Such a policy, according to Raffles, was "contrary to all principles of natural justice, and unworthy of any enlightened and civilized nation" (Raffles 1817: 255-7; cf. Reid 1993: 325). The destruction of indigenous trade and prosperity forced the Malays to turn to plunder and piracy in order to recover what they had been deprived of by policy and fraud. The greedy policy of the Dutch, instead of advancing the civilization and increasing the prosperity of the archipelago, brought ruin and desolation for the Malays, according to Raffles (Raffles 1830 [1819]: 10-1).

This analysis led Raffles to take a more optimistic view of the prospects for the British to promote civilization among the Malays. The Malays, he argued, were more open to new customs and ideas than the more civilized people of India, and even Islam, as practiced among the Malays, was now - in contrast to his earlier assessment - characterized by a moderate and temperate spirit. He lauded the Malay sense of honour and habits of reasoning and reflection, as well as their polite and courteous manners, all of which, Raffles argued, provided a basis for their advancement and even made them "congenial to British minds", their piracy and other vices notwithstanding. "Among many of them", Raffles concluded, "traces of a former higher state of civilization are obvious, and where the opportunity has been afforded, even in our own times, they have been found capable of receiving the highest state of intellectual improvement." (Raffles 1830 [1819]: 20-1; quote, 21).

2 The term 'robber-religion' was only used by Raffles in a letter to Lord Minto, written 1811 or 1812 and published posthumously in 1830, but was left out when an extract from the letter was published as part of the first edition of The History of Java (1817: 233). The same happened with the phrase 'to be cured by reasoning'. 
Raffles had by now also changed his mind about how to put an end to piracy. Rather than advocating, as he had done a few years earlier, the strong hand, he now foresaw a swift end to the practice through the adoption of a liberal economic policy and the promotion of free trade under British protection:

We may look forward to an early abolition of piracy and illicit traffic, when the seas shall be open to the free current of commerce, and when the British flag shall wave over them in protection of its freedom, and in promotion of its spirit. Restriction and oppression have too often converted their shores to scenes of rapine and violence, but an opposite policy and more enlightened principles will, ere long, subdue and remove the evil. (Raffles 1830 [1819]: 20)

Raffles proposed the establishment of a number of emporia in the Archipelago, which would serve both as commercial hubs and as exemplary centres of civilization for the Malays, who were thus to be free to adopt and apply the "arts and rules of civilized life" voluntarily and at their own pace. This policy was implemented in practice with the founding, at Raffles' instigation, of Singapore in 1819, which quickly developed into a major commercial hub in the Archipelago.

Contrary to Raffles' prediction, however, the establishment of Singapore as a node of British civilization in the region did not lead to the swift abolition of piracy. The increased commerce combined with the ready availability of European-manufactured arms and munitions and the lack of regulations and policing capacity instead meant that Singapore because a formidable base for launching pirate expeditions. Pirates of both Malay and Chinese origin were drawn to the port (Mills (1960 [1925]: 263; Chew 2012: 174-5; Eklöf Amirell 2019, forthcoming). Piracy thus continued to be a major threat to maritime commerce until the middle of the century, and the adoption of British civilization among the neighbouring Malay states seemed slow or even insignificant.

Raffles was the first British observer who attempted to systematically study piracy in the Malay Archipelago and who tried to understand the phenomenon historically. His views on the subject developed over the course of the 1810s, possibly as a result of his increasing knowledge of Malay history and culture, but obviously also in order for his observations to fit with his political agenda. Raffles was highly critical of the Dutch administration of the East Indies, and towards 1819 he seems to have become convinced that Malay piracy was the result of the marginalisation of the indigenous population caused by the unjust monopolistic commercial policies of the Dutch East India Company. Such an analysis went hand in hand with Raffles' advocacy of free trade and of a greater British influence in the Archipelago. Revising his earlier argument that piracy was an ancient evil and an integral part of Malay culture also served to strengthen the commercial prospects for the British in the region. The prosperity that free trade would bring to the Malays, Raffles believed, would soon put an end to piracy, and the Malays, given their fundamentally good character and former civilized state, would soon be able to progress toward higher levels of civilization. The role of the British, in that context, was to provide a role model of civilization in the region and to maintain maritime security so that free trade could flourish. 


\section{"Barbarous and poor, therefore rapacious, faithless, and sanguinary"}

Next to Raffles, the main British authority on Malay piracy (and Malay culture in general) in the nineteenth century was John Crawfurd, a Scottish physician and colonial administrator who, among other things, served as Resident-Governor of Yogyakarta in Java under Raffles and as Resident of Singapore from 1823 to 1826 . He was a prolific writer throughout his long life (1783-1868) on a wide range of subjects, including Malay history, language and culture. In many respects, particularly in his advocacy of free trade and economic development, his views were close to those of Raffles. Like Raffles, Crawfurd also saw the similarities between piracy in the contemporary Malay world and ancient Greece, a comparison which he pursued with reference to Thucydides (Crawfurd 1856: 353-4). Crawfurd dealt with the subject of Malay piracy at more length and in greater detail than Raffles, and he was more prone than his former superior to explain it in terms of race and the alleged lack of civilization on the part of the Malays.

In an anonymous article entitled "Malay Pirates", which was most likely written by Crawfurd and originally published in the Singapore Chronicle when Crawfurd was the Resident of Singapore, he stressed the importance of the geography of the Malay Archipelago as a fundamental reason for the prevalence of piracy. There were many suitable hiding places and islands from which pirates could prey on the busy commercial traffic passing through the region, according to Crawfurd. A large proportion of the population lived on the coasts or around the estuaries of rivers, and according to the author, they were "barbarous and poor, therefore rapacious, faithless, and sanguinary". These circumstances supposedly explained the origins of their 'piratical character', and what was remarkable, following Crawfurd, was not the prevalence of piracy among the Malays, but rather that the problem was not worse than it was. This, Crawfurd explained, was due to the "feeble and unenterprizing character" of the population. Had the Archipelago been populated by a race of European buccaneers it would soon have become impassable for most of the commercial vessels that now navigated in the area (Crawfurd 1825: 243).

Crawfurd also acknowledged the detrimental effects of the European incursions in the region in the past. Although he seemed less convinced than Raffles that the Dutch policy was the main explanation for the prevalence of Malay piracy, he did acknowledge that the use of sea power by early modern European navigators (particularly the Dutch, but also the Spanish, the Portuguese and the English) to further their commercial objectives encouraged piratical activity among the Malays. Such conduct, he wrote, "brought the European character into the greatest discredit with all the natives of the Archipelago, and the piratical character which we have attempted to fix upon them, might be most truly retaliated upon us" (Crawfurd 1820b: 235; cf. 221-2).

Crawfurd was decidedly more negative than Raffles in his opinions about the indigenous population of the Malay Archipelago. In contrast to Raffles' optimism with regard to their potential for progress, Crawfurd held the Malays to be 'by far the most uncivilized and barbarous' of all the people of the East with whom Europeans had had commercial relations (Crawfurd 1820a: 72). Virtually all maritime peoples of the Archipelago had, according to Crawfurd, at one time or another, practiced piracy, and he traced the historical references to piracy in the region back to the fourteenth century in order to demonstrate its entrenched and 
persistent character. Piracy in his own time was most prolific among 'rude and lawless tribes of fishermen' who did not regularly engage in agriculture or trade, and those who were most addicted to piracy were also the most idle and least industrious, according to Crawfurd. By contrast, the more civilized inhabitants of Java, Bali, Lombok, much of Sumatra (except the maritime Malays), Sulawesi (except all mariners) and the Philippines under Spanish control (except the predominantly Muslim population of the southern Philippines) did not practice piracy, at least not in recent times (Crawfurd 1825: 243; 1856: 354).

The surest way to put an end to piracy was encourage industrious habits among the indigenous population. In Crawfurd's mind, piracy was a barbarian residue that would disappear with the progress of civilization, and the absence of piracy among the more civilized and agricultural peoples of the Archipelago, such as the Javanese and Filipinos, seemed to confirm this theory. The only way for the British to encourage industry among the Malays was to provide them with a ready and free market where they could profitably and honestly trade their products. As the most prominent members of the piratical communities would prosper from the trade with the British, they would join the latter in the efforts to suppress piracy, and commerce would be seen as honourable while piracy simultaneously would become hazardous and disreputable. Several Malay princes had, according to Crawfurd, already come to realize that honest trade, rather than piracy or the sponsoring of piracy, was in their best interest, including the Rajas of Terengganu, Kelantan, Pontianak and Johor (Crawfurd 1825: 243, 245).

The encouragement of trade should be accompanied by resolute efforts to suppress piracy, including close collaboration with other colonial governments, regular patrols by steam vessels, strong retributions against indigenous rulers who harboured pirates and the destruction of some of the most notable pirate haunts to serve as an example (Crawfurd 1825: 245).

The last tactic - to attack and destroy the suspected pirates' villages as well as their means of livelihood - was practiced, to varying degrees, by all European colonial powers in maritime Southeast Asia during the first half of the nineteenth century (and sometimes later as well) and was often accompanied by great destruction of human life and property. Like Raffles before him, however, Crawfurd in time changed his opinion about the wisdom of such repressive measures. In 1856 he wrote:

The destruction of the supposed haunts of the pirates by large and costly expeditions, seems by no means an expedient plan for the suppression of piracy. In such expeditions the innocent are punished with the guilty; and by the destruction of property which accompanies them, both parties are deprived of the future means of honest livelihood, and hence forced, as it were, to a continuance of their piratical habits. The total failure of all such expeditions on the part of the Spaniards, for a period of near three centuries, ought to be a sufficient warning against undertaking them. (Crawfurd 1856: 355)

Compared with Raffles, Crawfurd was thus much more prone to explain Southeast Asian piracy in terms of the alleged lack of civilization on the part of the Malays - particularly the maritime Malays, by which Crawfurd meant fishermen, mariners and other Malay-speakers who lived by the sea and whose main livelihood did not derive from cultivation. He was also markedly more negative in his assessment of the Malays as a nation or race, and he did not see any of the traces of a formerly great civilization among them, as Raffles had done. 
However, even though Crawfurd ascribed the propensity to engage in piracy to an inherent deficiency in the Malay character, he believed that they could be civilized and improved upon. To that effect he concurred with Raffles (and many other British observers at the time) that the promotion of free trade was the only way for the British to bring prosperity and civilization to the Malays and to put an end to their piratical habits.

With regard to the use of violence, Crawfurd changed his mind over the course of the three decades between the mid-1820 and the mid-1850s and eventually rejected the policy of destroying the land bases of suspected pirate communities, something which he had advocated during his term as Resident of Singapore. Although he cited the allegedly failed Spanish policy since the sixteenth century of wholesale destruction of suspected pirate haunts in the southern Philippines as a deterrent, his opposition to the more recent efforts of James Brooke to suppress piracy and colonize North Borneo was probably a more important factor in his change of heart (see Knapman 2017: 181-4, 192-6).

\section{"The pirate haunts must be burned and destroyed"}

James Brooke was a British soldier and adventurer who in 1841 was installed as the Raja of Sarawak in North Borneo by the Sultan of Brunei, Omar Ali Saifuddien II, after having helped the Sultan to crush an uprising against his rule. For the British government, Brooke's rise to power was troublesome, but not completely unwelcome. On the one hand the government worried about the apparent power vacuum in North Borneo, which might lead to another colonial power gaining a foothold in the area and thereby weaken Britain's influence in the region. On the other hand, Brooke's styling of himself as a white raja seemed like an anachronism and a potential embarrassment to Great Britain and its endeavour to be a model of civilization and progress. In more pragmatic terms, the government was also anxious to avoid costly colonial wars or additional administrative burdens resulting from an unplanned territorial expansion (see Webster 1998: 111-34; Walker 2002).

In this context, allegations of piracy on the coast of North Borneo served Brooke well, both to secure naval support for his colonial ambitions and to win public support for his cause in Britain. His success in casting himself as a pirate hunter and benevolent harbinger of civilization to the indigenous population of North Borneo - many of whom seemed to be victims of the pirates' depredations - turned him into a Victorian celebrity. Throughout most of the 1840s, Brooke and his supporters in Great Britain managed to capture the humanitarian agenda with regard to the British involvement in North Borneo (Knapman 2017: 183). Brooke received the Order of Bath in 1847 and was knighted by the Queen the following year. Soon after, however, his reputation was tarnished by allegations that he had promoted the use of excessive and indiscriminate violence in his efforts to suppress piracy, leading to the killing of numerous innocent people. The criticism against him and the volte-face in public opinion brought an end to official British support for his expansionist policy around 1850 (Tarling 1999: 19-20).

Brooke was a prolific journal and letter writer, but he did not leave a consistent body of ideas, and his opinions about the situation in Borneo sometimes changed from day to day. Apart from Brooke's own attempts to justify his action several of his followers also argued on his behalf, lauding his supposedly unselfish attempts to suppress piracy and bring 
civilization to the savages of Borneo while advancing British commercial interests in the region (Knapman 2016: 154). For example, to "carry the Malay races, so long the terror of the European merchant-vessels, the blessings of civilization, to suppress piracy, and extirpate the slave-trade, became his humane and generous objects", wrote his good friend Henry Keppel (1846: 2), who commanded the Royal Navy's corvette H.M.S. Dido on an expedition to suppress piracy on the North Borneo coast in the mid-1840s, at Brooke's behest.

Keppel was relatively clear and consistent as to the origins of piracy, not only in the Malay Archipelago but in world history in general. Taking a Hobbesian view, Keppel argued that piracy always had its origin in opportunity, and given favourable geographic conditions, piracy was bound to spring up. Especially in an archipelago, piracy had always been the natural state of things, and, consequently, the "barbarous or semi-barbarous inhabitant of the [Malay] Archipelago, born and bred in this position, is born and bred a thief." (Keppel 1853: 281)

Brooke concurred with Keppel about piracy being a manifestation of the allegedly uncivilized nature of the Malays. "Amongst the Malays, piracy is a national feeling, it is a part of their code of honour, encouraged by their education and habits, and too often fostered by impunity", he wrote in a letter to a friend in 1843 (Brooke 1853a: 277). According to Brooke, the Iranun of the southern Philippines - who for good reason were considered to be the most formidable pirates in the Archipelago - also defended their depredations with reference to the custom and mode of life of their ancestors (Brooke 1848a: 240-1). ${ }^{3}$

A further explanation to the prevalence of piracy offered by Brooke was the lack of law enforcement and other shortcomings on the part of the Malay states. In an official memorandum on piracy written in 1844, he emphasized the condition of the indigenous governments and the "total absence of all restraint from European nations", combined with the local geography, as reasons for the flourishing of the pirate communities in the region (Brooke [1844] 1846: 302). In a letter from 1845, he further touched on the subject of law and sovereignty in relation to piracy:

The piracy of the Archipelago is not understood; folks, naval officers in particular, talk about native states, international law, the right of native nations to war one on another, \&c., \&c.; and the consequence is they are very reluctant to act, because they cannot distinguish pirate communities from native states. Some broad and general principle should be laid down, and native states or no native states, I would punish them if they dare to seize a trader on the high seas. (Brooke 1853b: 63; cf. Brooke [1844] 1846: 308; Benton \& Ford 2016: 141)

In line with Raffles and Crawfurd, Brooke saw piracy as part of the character of the Malays and other maritime ethnic groups in the Archipelago, and he believed that whole communities of alleged pirates, rather than individual wrong-doers, should be punished:

I have always urged, that, to eradicate piracy, a force must be sent to the pirate haunts, to burn and destroy their towns. Merely to cruize is to harass your own men, and to gain but very partial and occasional success; but what pirate would venture on his evil course if his home were endangered, - if he be made to feel, in his person, the very ills and miseries he inflicts upon others. Of course this retribution must be inflicted on all classes of pirates: on pirates

3 Iranun piracy and maritime raiding, however, was of relatively recent origin, taking off only from around 1770; see Warren (2002: 25-6; passim) 
direct, and pirates indirect; on the aiders and abettors, as well as the actual perpetrators; $[\ldots]$ for the encouragers of theft, and the receivers of stolen goods, knowing them to have been stolen, are to be punished in like manner with the thief himself. (Brooke 1848b: 12-3)

Such ideas about collective guilt and guilt by association when it came to piracy in Southeast Asia also influenced British legal practices. In 1845, the High Court of Admiralty ruled that the killing of thirty alleged pirates and the capture of another twenty-five near the Island of Sarassan (Serasan) in the Natunas, off the north-west coast of Borneo, two years earlier had been justified even though there was no positive evidence of any act of piracy. According to High Admiralty Judge Stephen Lushington, it was sufficient "to clothe their conduct with a piratical character if they were armed and prepared to commence a piratical attack upon any other persons" (British International Law Cases 1965: 779; cf. Rubin 1988: 230-2).

The Royal Navy (and the East India Company) - including its officers, sailors, marines and soldiers - also had a strong financial incentive to adopt a broad definition of piracy and to kill, capture or disperse as many alleged pirates as possible. According to the Bounty Act of 1825 (6 Geo. 4 c. 49), those who took part in an engagement with so-called piratical persons (without further elaborating on what the defining characteristics of such persons were) were to receive $£ 20$ for each pirate killed or captured and $£ 5$ for each dispersed (Tarling 1978: 101). These provisions probably significantly increased the willingness of the Royal Navy to lend their assistance to Brooke's anti-piracy campaigns.

In spite of the difficulties to decide which groups could be reasonably regarded as piratical and which could not, Brooke argued for a sharp distinction in the treatment of piratical states as opposed to friendly states or communities:

We must make a broad distinction between piracy and no piracy. We must take care of our honest friends, and prove to them, the advantages of honesty. We must leave an opening for amendment, and trust (wherever it is possible to adopt such a course) to the promises of reformation made by the pirate communities; but when once these promises are duly understood, we must inflict punishment for every breach of them, and for every species of piracy, and we ought to act with perseverance and a rapidity which would take their breath away. (Brooke 1848b: 86)

The repressive policy urged by Brooke was implemented in a series of engagements with alleged pirates in the second half of the 1840s. The most lethal took place in 1849, when the British attacked and destroyed several suspected pirate villages at Batang Marau in Sarawak and killed at least five hundred, and possibly more than a thousand, allegedly piratical Ibans (also known as Sea Dayaks). The event caused some commotion in Britain the following year, when the government asked Parliament for more than $£ 20000$ to satisfy claims for head money due to the so-called Battle of Batang Marau, which comprised more than a fifth of the total bounty of $£ 100000$ that year (Tarling 1978: 136).

At stake was not only the exorbitant amounts to be paid out from the public purse; the affair also drew attention to the brutality of the anti-piracy measures advocated and implemented by Brooke and his followers. A campaign was launched by the Radical Party in Parliament against Brooke and the ruthless anti-piracy measures that he advocated, together with the Aboriginal Protection Society and tacit support from Crawfurd. In 1851 Richard Cobden, a Radical Member of Parliament and a leader of the Liberal Manchester School, said of Batang Marau: 
The loss of life was greater than in the case of the English at Trafalgar, Copenhagen, or Algiers, and yet it was thought to pass over such a loss of human life as if they were so many dogs; and, worse, to mix up professions of religion and adhesion to Christianity with the massacre. If the country had not moral force enough to compel this inquiry [against Brooke], then let it cease its comments on other countries, in whose eyes the people of England wished to set themselves up as examples of morality, magnanimity, and all the other virtues." (House of Commons Debate, 10 July 1851, vol. 118: 498-9)

The Radicals tried, but failed, to block the payment of the head money in 1849, but in the following year they managed to have the Bounty Act of 1825 repealed and replaced with a less costly provision for the payment of prize money. Brooke's opponents also succeeded in having a Commission of Inquiry appointed, which in 1854, however, resulted in his exoneration from all charges against him. The official support for Brooke and his activities was nevertheless discontinued, and he could henceforth no longer call on the Royal Navy to carry out his anti-piracy operations (Knapman 2017: 196-200).

\section{"The most daring and bloodthirsty of all"}

In June 1871, the Acting Governor of the Strait Settlements, Colonel Edward Anson, received information about a pirate attack in which thirty-four men, women and children supposedly were murdered in the Strait of Malacca after leaving the British port of Penang for Larut in the Sultanate of Perak on the junk Kim Seng Cheong. According to '[s]ome information' received by the Chinese owners of the junk, the perpetrators were fourteen Chinese who had boarded the junk as passengers shortly after departure from Penang. Once at sea, they reportedly took over the vessel, murdered the whole crew and all passengers and threw the bodies overboard. After making investigations in Penang, one of the owners of the junk set off on a steamer bound for Singapore to seek the assistance of the Governor in order to find out what had happened to the junk. En route to Singapore, the owner serendipitously spotted the junk sailing close to the Selangor coast. Governor Anson, upon receiving this information, dispatched the colonial steamer Pluto to Selangor. The expedition encountered the junk - quite unexpectedly, according to Anson - and managed to secure the vessel and most of the cargo. The British also managed to apprehend nine of the suspected pirates, but met with resistance when they landed and tried to seize the remaining five (Parliamentary Papers C.466: 1$)^{4}$

Anson requested the assistance of the Royal Navy's gunboat Rinaldo, which happened to be in the neighbourhood. The Rinaldo, reinforced with troops from Penang, proceeded to Selangor where they dispersed the alleged pirates and their suspected accomplices, who were believed to be based in a fort at the mouth of the Selangor River. "We spent the day in utterly destroying this nest of pirates", the Commander of the Rinaldo, Captain Robinson, smugly noted in his report of the operation, which subsequently was published in the London Times (5 September 1871). "The town of Salangore is completely burnt down, the forts demolished, the guns spiked and broken up [...] Five piratical prows were burnt, three with two 24pounders and one small gun each" (Parliamentary Papers C.466: 10, 37-8). 


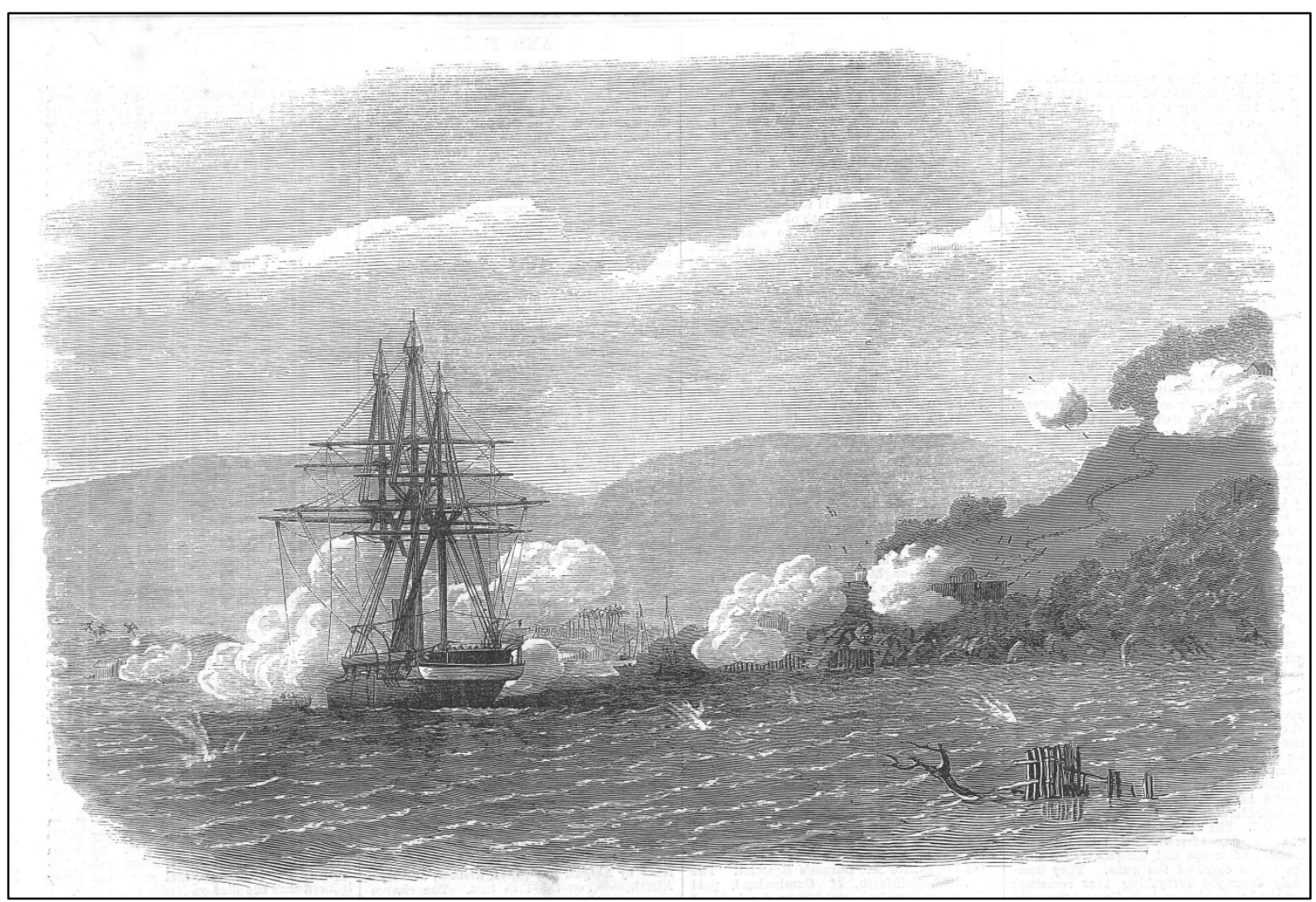

Illustration 1. "H.M.S. Rinaldo bombarding Salangore, in the Strait of Malacca" (Cropped image)

Anson, Robinson and many senior Straits Settlements officials concurred that the destruction of Selangor was likely to have a salutary effect and that no further acts of piracy were likely to emanate from Selangor for a long time (Parliamentary Papers C.466: 2, 10). However, there had in fact been very few reported pirate attacks emanating from Selangor in the preceding years. Anson himself admitted as much in a letter to the Secretary for the Colonies, the Earl of Kimberley, following the so-called Selangor incident, admitting only that there 'had been from time to time complaints of petty piracies along the Malay coast, but it was always supposed that they were committed by small gangs of Malays of bad character, and there was no knowledge of any organized gang of pirates'. Neither did the merchants of Penang and Singapore who traded with Selangor suspect that the Selangor Fort was a nest of pirates, or at the very least they made no communication to the Straits government about it, according to Anson (Parliamentary Papers C.466: 36).

Against this background, it appears that main objective of the intervention was not to suppress piracy but to have the son-in-law of Sultan Abdul Samad of Selangor, the Britishfriendly Tengku Dhiauddin Zainal Rashid, also known as Tunku Kudin, installed as regent. If Tunku Kudin were to receive the support of the British, Anson and other senior colonial officials believed, he would be able to put an end to the unrest and civil war which for several years had plagued Selangor, and create favourable conditions for trade and investment in the Sultanate (Parliamentary Papers C.466: 28; cf. Gullick 1986). To this effect, Anson, supported by senior colonial administrators and naval officers in the region, seized the opportunity to intervene in Selangor offered by the reported attack on the Kim Seng Cheong. 
The lack of substantial evidence of organized piracy emanating from Selangor was troublesome for the Straits authorities, however. Moreover, the alleged pirate attack that had triggered the intervention had not emanated from Selangor but from the vicinity of Penang, which was a British port. Sharp criticism of the intervention was voiced in in London, leading the government to take a more cautious non-interventionist policy in relation to the Malay states in the following years. From the end of 1873, however, the official policy of noninterference in the internal affairs of the Malay states changed in favour of a more assertive and interventionist policy that eventually would lead to the colonization by Great Britain of most of the Malay Peninsula (Tarling 1999: 28-9; Cowan 1961).

In November 1873, Lieutenant-Colonel Andrew Clarke, a reputed man of action and an experienced military officer, was installed as Governor of the Straits Settlements, bringing with him a more far-reaching mandate from London for intervention in Selangor and other unstable or unfriendly Malay states. Clarke was adamant about how the British should act in relation to the Malay states:

The Malays, like every other rude Eastern nation, require to be treated much more like children, and to be taught; and this especially in all matters of improvement, whether in the question of good government and organization, or of material improvement by opening means of communication, extending cultivation, and fostering immigration and trade. (Parliamentary Papers C.1111: 110)

Clarke's first priority was to intervene in Perak, where maritime raiding and other forms of banditry were indeed frequent because of the civil unrest involving rival claimants to the throne and rival Chinese societies engaged in tin mining. In Selangor, by contrast, there were still very few cases of piracy, but this circumstance that did not stop the Straits government from making a renewed effort to portray Selangor as a formidable pirate lair. The main responsibility for doing so fell to the Attorney-General of the Straits Settlements, Thomas Braddell, who was a reputed authority and amateur scholar of Malay history and culture (cf. Makepeace 1921: 425-6). Seizing upon a rare and violent case of piracy against a local trading boat at the mouth of the Jugra River on the Selangor coast in November 1873, Braddell wrote in an official report:

The Salangore pirates are distinguished in the Malayan seas as the most daring and bloodthirsty of all. They are said to be supported by nobles, and even by members of the Royal Family, and are led by men of rank, of Bugghese descent, who are superior in warlike qualities to the ordinary Malayan Chiefs.

$[\ldots]$

The coasts of Salangore are peculiarly well situated as a refuge and haunt for pirates. [...] The numerous rivers, great and small, between the Salangore and Lingie Rivers, afford shelter for pirates, who have stockaded defences up the creeks, from which they sally forth to attack the boats which pass close to their stations, making for the Calang Straits. When their work is done, the pirates retire to their strongholds, which are out of sight, and, practically, out of reach of the men-of-war cruizing in these seas.

$[\ldots]$

The piratical practices at Salangore differed from those in other parts of the peninsula, in this; that they were continuous, well organized, and more daringly carried out; showing that they 
were not, as in other places, caused by temporary difficulties in the country, and ceasing with those difficulties, but were the result of long-continued lawlessness in the people, and protected, if not caused, by persons of rank in the country. (Parl. Pap. C.1111: 185, 186)

Braddell's explanation was essentially the same as that which had been advanced by Brooke and his supporters three decades earlier, that is, a combination of inherent racial factors, opportunity offered by geography and the lack of law and order, resulting in a longstanding and institutionalized system of piracy. The course of action taken by Governor Anson and the Straits government in 1871 was also similar to that advocated by Brooke - to destroy the pirate bases - although the use of violence was much more restrained than in the operations instigated by Brooke, with only a handful of reported casualties among the alleged pirates and the British. In 1874, moreover, Governor Clarke managed to have a British Resident to Selangor appointed, after the Sultan, literally at gunpoint, with the guns of the Royal Navy's gunboat Teazer pointing at his palace, had been forced to cede to British demands (Eklöf Amirell 2019, forthcoming, Ch. 3).

In the negotiation, Clarke raised the 'unpleasant' subject of piracy with the Sultan, explaining that the piracies emanating from Selangor risked bringing down the 'reprobation of the whole civilized world' on the Sultan (Parliamentary Papers C.1111: 193). In order to impress upon those in Selangor who might be inclined to engage in piracy, Clarke ordered that a trial be held in Selangor, supervised by two Malay-speaking British commissioners, against the suspected perpetrators of the Jugra River piracy in November 1873. The idea was for the trial to set an example in Selangor and at the same time avoid the risk that the case be rejected in a British court of law for being outside British jurisdiction. The outcome of the trial at first seemed satisfactory from the British point of view: All of the eight accused men were convicted and all but one, a teenager who was pardoned, were executed with a kris (dagger), which Sultan Abdul Samad, to the satisfaction of the British, provided for the purpose. However, it later transpired that the trial had suffered from several deficiencies, and Frank Swettenham, who served as the British Resident to Selangor in the 1880s, was convinced that those who were executed in fact were innocent and that the real culprits still remained at large (Parliamentary Papers C.1111: 181; Swettenham 1907: 184; cf. Gullick 1996).

\section{"A blush of shame and indignation on every English face"}

About a week after the publication in The Times of Commander Robinson's report on the destruction of Selangor, on 13 September 1871, a letter to the editor entitled "The destruction of Salangore" appeared in the newspaper. The author was Peter Benson Maxwell, an outspoken Irish lawyer who strongly believed in the perfection of British justice and saw it as a duty for the British to promote justice and the rule of law around the world. He had retired from his position as Chief Justice of the Straits Settlements and returned to England less than half a year earlier, after having served in the Straits judiciary for altogether more than fifteen years, first as a recorder and then as chief justice. During his term in the Straits Settlements, Maxwell had consistently stood up for the integrity of the courts vis-à-vis the executive, which had led to a strained relationship between the two branches of the colonial government (Turnbull 1957: 137, 160-1; Cowan 1961: 95). As a longstanding and leading colonial 
official, Maxwell apparently had intimate knowledge about the relations of the British colony with the neighbouring Malay states and the political situation in Selangor. He was also familiar with the pirate incidents that still from time to time occurred in the Strait of Malacca, in spite of the success of the British and other colonial and indigenous governments in suppressing piracy in the region over the previous decades. In March 1871, Maxwell had presided over a trial that resulted in harsh sentences for forty-nine Malays who were responsible for a relatively minor robbery of a ship off the coast of Selangor (Straits Times Overland Journal, 20 December 1870; 15, 29 March 1871).

Maxwell, in his letter to The Times, took a juridical view of piracy in the Strait of Malacca. Citing Singapore's leading newspaper, the Straits Times, he claimed that piracy had ceased to exist as a system in the Malay Peninsula and that there were no professional pirates or pirate-states left - only occasional acts of piracy and robberies at sea, which should be handled through regular legal procedure. In contrast, according to Maxwell the intervention in Selangor was an unjustifiable act of war, ordered by an acting governor who had no authority to wage war on a sovereign state. Such exploits, Maxwell concluded 'should raise a blush of shame and indignation on every English face. They can bring only discredit and hatred upon us, and if they are not sternly repudiated by our Government the face of England, in Oriental idiom, will be blackened, and her name will stink' (Maxwell 1871).

Following the Selangor incident, Maxwell continued to criticize the British expansion in the Malay Peninsula, which, as we have seen, intensified with the appointment of Andrew Clarke as governor of the Straits Settlements at the end of 1873. In 1878, Maxwell published a pamphlet, dedicated to the Aborigines Protection Society and entitled Our Malay conquests, in which he briefly outlined and denounced the British policy in the Malay Peninsula in the preceding years. However, in spite of Maxwell's stern defence of the Malay states against the British onslaught, there was no doubt in his mind about the inferiority of the Malays as a race. "The Malays have the defects or vices which are found in other weak and down-trodden races," he wrote, adding that they were "in general invincibly lazy" and "often false, deceitful, tricky, treacherous", although he also pointed out some more positive racial characteristics, such as affection, gentleness and dignity of manner (Maxwell 1878: 4). He was less positive with regard to the privileged classes, however, claiming that they lived "in the same idleness as other barbarous aristocracies, oppressing and plundering the unprivileged class" similarly to how French seigneurs and administrators had done before the Revolution (Maxwell 1878: 5). These barbarous aristocrats and the lack of a central authority capable of imposing law and order were, according to Maxwell, the origins of what traders and colonists called piracy:

When the chief authority is defied, or his succession is disputed, the Sultan rarely interferes to restore peace, any more than a king of France or emperor of Germany troubled himself with the private wars of his counts and barons. He deems it no part of his duty, and he has no adequate means to do so. The times then become more than usually evil for the inhabitants, on whom double taxes and exactions are inflicted by the contending claimants. The trader, too, who ventures up a Malay river at such times, is subjected to the same duplication of charges, and finds himself the principal contributor to the sinews of the war. Irritated, he returns to the colony, calling both sides "pirates." The term is adopted readily by the European colonists; and even governors and officials take it up and apply it indiscriminately to all who levy a kind of due with which European commerce was familiar for centuries, and the last of which 
disappeared only the other day in the Sound. It is impossible to estimate the amount of injustice done by this idle misapplication of a vituperative term; for it leads those who do not take the trouble of stripping facts of the colouring in which they are presented, to form very erroneous conceptions of the truth, and to deny to the objects of it every human right. (Maxwell 1878: $5-6)$

In contrast, Maxwell claimed that there were no grounds for suspecting the Malay states of committing or sanctioning "anything like real piracy", and that there had been no such statesponsored piracy in the Malay Peninsula for over forty years (Maxwell 1878: 6).

In an appendix to the book dedicated to piracy, Maxwell went on to repudiate the unfounded accusations of Braddell and other colonial officials against Perak and Selangor for sponsoring and harbouring pirates. Drawing on his personal experience of fifteen years of service in the Straits Settlement's judiciary, he claimed that "no crime was rarer in the calendar of the Straits courts than piracy". According to Maxwell, there had been only three incidents that might qualify as piracy on the Selangor coast in recent years. Of these, two were relatively minor, and one (the Jugra River piracy), while serious, occurred so close to the Selangor coast that it was outside British jurisdiction (Maxwell 1878: 122).

Although Maxwell shared many of the stereotypical images and prejudices of other European observers at the time with regard to the Malays, he did not see an inclination to piracy as part of their racial constitution. Instead, he saw the primitive political system and instability - which he compared to that of mediaeval Europe - as the origin of what European traders and colonizers inappropriately called piracy. If a system of institutionalised piracy, in the true sense of the word, had ever existed in the Malay Peninsula (a question that Maxwell did not discuss directly) it had all but come to an end already by the 1830 s, if not before. Consequently, the occasional pirate raids that still occurred should be dealt with by regular legal procedure and not by military intervention or colonisation. The responsibility for dealing with alleged pirates, moreover, should not be the responsibility of the British outside their jurisdiction. Instead, Maxwell trusted that the authorities of Selangor and other Malay states would prosecute suspected pirates operating in or dwelling in their territory. By this assumption Maxwell also implicitly assumed that the Malay states met the so-called standard of civilization (Gong 1984; cf. Koskenniemi 2001), that is, that they qualified as civilized states and members of the international community because of their adherence to the rule of law - notwithstanding his largely negative assessment of the Malays, both with regard to their culture and their political system.

\section{Conclusion}

After the middle of the eighteenth century, piracy, in the eyes of the British and other Europeans, became increasingly linked to race and civilization, or rather lack of civilization. After the end of the Golden Age of Atlantic piracy around 1730, the pirates of greatest concern to European states and colonizers around the world seemed to be for the most part to be of non-European nationality. Along with the Arabs of North Africa and Oman, the Malays were seen as particularly addicted to piracy, but there was considerable disagreement among nineteenth-century British (and other European) observers about the reasons for this alleged addiction. 
Many observers saw the opportunities provided by the geography of the Malay Archipelago as a precondition for piracy, but it was generally seen as a necessary, rather than sufficient, explanation. In addition to the geographical factor, three main lines of argument can be distinguished among the nineteenth-century British observers that have been under study here, all of whom exercised considerable influence in their own time, and in some cases well beyond. The three lines were not necessarily mutually exclusive, and there was often considerable inconsistency in the arguments proposed by any one observer. Nevertheless, distinguishing the following three lines of argument is useful for the purpose of discerning the streams of ideas about piracy and its remedies among nineteenth-century British observers and actors in the Malay Archipelago.

The first line of argument was racial and cultural, and was partially, but not exclusively, linked to the geography. For example, Raffles - at least in his earlier writings - argued that piracy was an ancient, culturally sanctioned practice among the Malays and that it had been further reinforced by the introduction of Islam in the region. Later observers, from Crawfurd to Maxwell, regardless of the means which they advocated to suppress piracy, saw piracy as a manifestation of the lack of civilization on the part of the Malays, both with regard to their cultural development and their social and political system.

Many writers, including Raffles, Crawfurd and Maxwell, used historical analogies to understand the racial and cultural aspects of piracy, comparing the stage of civilization among contemporary Malays to that of pre-classical Greece or mediaeval Europe. This explanation was consistent with the contemporary historicist understanding of the world as being inhabited by numerous and relatively distinct nations or races displaying different stages of development. According to this line of argument, certain races were inherently piratical - whether directly or indirectly involved in piracy - as a result of their level of civilization. Harsh measures, such as wholesale killings and the destruction of alleged pirate nests, were often suggested and implemented in order to eradicate the problem, culminating with the massacres in North Borneo, perpetrated by the Royal Navy at the behest of James Brooke, in the 1840s. Essentially, this was a policy designed to "Exterminate all the brutes", as put by Joseph Conrad in Heart of Darkness and later explored in the context of European colonialism by the Swedish author Sven Lindqvist (1996 [1992]).

The second line of explanation was economic and historical. Raffles, and to a lesser degree Crawfurd, saw piracy as a result of the European - particularly the Dutch - incursions in Southeast Asia, which had resulted in a long-standing decline for indigenous traders and polities. This argument meshed well with the advocacy by Raffles and other British colonizers of free trade, which, they believed, would create favourable conditions for economic development based on trade and the production of export commodities rather than plunder and enslavement. This line of argument was generally associated with less repressive measures, and the most important task of the British in the Malay Archipelago would be to provide favourable conditions for trade, including the protection of maritime commerce and the establishment of entrepôts for trade. In addition, the British should establish a model of civilization and good governance at the heart of the Archipelago.

The third line of argument was that piracy flourished because of a general lack of law and order. This in turn was linked to the rude, barbarous or semi-civilized - depending on the observer's point of view - state of the legal and political system of the Malays. Although 
some observers, such as Raffles and Crawfurd, realized that the political situation, at least in part, was a consequence of the European incursions since the beginning of the early modern period, they were often less clear about the negative impact of the processes set in motion by the intensified colonial presence and economic exploitation in the region in the nineteenth century. These included, among other things, the import of European-manufactured arms and munitions and an influx of large numbers of Chinese and European immigrants.

It seemed to follow from the last line of reasoning that one of the most important tasks of the British was to see to it that the rule of law was upheld in the Archipelago and that pirates were brought to justice regardless of where they were based or operated. Doing so was not just a matter of law and order, but also of civilization, because the quality of a country's judicial system was seen as a yardstick of civilization. It is from this perspective that Clarke's order that the trial against the perpetrators of the Jugra river piracy in 1874 be held in Selangor should be understood. It is doubtful, however, that the desired effect was achieved, given that the result probably was the execution of seven innocent men, while the actual instigators and perpetrators of the attack remained at large. The outcome of the trial also casts doubt upon Maxwell's argument that the legal system of Selangor was able to deal effectively with piracy, and it is perhaps significant that he chose not to discuss the trial in his pamphlet published in 1882, even though he had access to the proceedings of the trial.

For nineteenth-century Britons the suppression of piracy was not only about bringing civilization to the Malays, although this certainly was an important part of the argumentation of both those who were in favour of harsh repression, such as James Brooke and his followers, and those who advocated less violent measures, such as Raffles (in his later writings), Cobden, Crawfurd and Maxwell. A significant shift in this respect occurred in the middle of the nineteenth century. Throughout most of the 1840s James Brooke and his followers succeeded in representing themselves as the torchbearers of humanity and civilization, in spite of the massive destruction of life and property they caused in North Borneo. Brooke's broad and often arbitrary definition of piracy, combined with the excessive use of force and his disregard for the loss of life and property by the allegedly piratical communities, however, led to sharp criticism from 1849 and to a reversal of the official support for his ventures. The controversy not only affected Brooke and British policies in Borneo. It also led to a more cautious British policy in order to suppress piracy in Southeast Asia. The rejection of naval operations of mass destruction from around middle of the nineteenth century shows that humanitarian considerations were of some consequence in shaping British colonial policies in Southeast Asia. By showing restraint in the deployment of violence against supposedly less civilized peoples, whose military technology and strength was vastly inferior to that of the British, the latter could demonstrate their ostensibly advanced level of civilization, not only in relation to their Asian adversaries but also to other colonial powers. The fact that Britain showed such restraint in the Malay Archipelago during the second half of the nineteenth century, however, does not mean that she did so in other parts of the world. 


\section{Bibliography}

\section{Legal and official sources}

British International Law Cases: A Collection of Decisions of Courts in the British Isles on Points of International Law 3. London: Stevens \& Sons, 1965.

House of Commons Debate, 10 July 1851. Commons and Lords Hansard, Official Report of Debates in Parliament, vol. 118, cc 498-9. Digital version available at the URL http://hansard.millbanksystems.com/commons/1851/jul/10/borneo-sir-jamesbrooke\#S3V0118P0 18510710_HOC 49 (viewed 14 February 2018).

Parliamentary Papers C.1111: Correspondence relating to the affairs of certain native states in the Malay Peninsula, in the neighborhood of the Straits Settlements (In continuation of Command Paper 465 of 1872). Presented to both Houses of Parliament by Command of Her Majesty, July 31, 1874. London: Harrison and sons 1874.

C.466: Papers (with a map) relating to recent proceedings at Salangore consequent upon the seizure by pirates of a junk owned by Chinese merchants of Penang; and the murder of the passengers and crew. Presented to both Houses of Parliament by Command of Her Majesty. London: Harrison and sons 1872.

\section{Newspapers}

Singapore Chronicle (Singapore).

Straits Times (Singapore).

Straits Times Overland Journal (Singapore).

The Times (London).

\section{Books and other printed sources}

Brooke, James (1846 [1844]), "Mr Brooke's memorandum on piracy of the Malayan archipelago", in Henry Keppel, The Expedition to Borneo of H.M.S. Dido for the Suppression of Piracy. New Your Harper \& Brothers, pp. 302-14

-_ (1848a), Narrative of Events in Borneo and Celebes down to the Occupation of Labuan from the Journals of James Brooke, Esq. Rajah of Sarawak, and Governor of Labuan: Vol. I. Rodney Mundy (ed.). London: John Murray.

-_ (1848b), Narrative of Events in Borneo and Celebes down to the Occupation of Labuan from the Journals of James Brooke, Esq. Rajah of Sarawak, and Governor of Labuan: Vol. II, Rodney Mundy (ed.). London: John Murray.

-_ (1853a), Private Letters of Sir James Brooke, K.C.B. Rajah of Sarawak: Vol. I, John C. Templer (ed.). London: Richard Bentley.

-_ (1853b), Private Letters of Sir James Brooke, K.C.B. Rajah of Sarawak: Vol. II, John C. Templer (ed.). London: Richard Bentley.

Crawfurd, John (1820a), History of the Indian Archipelago: Vol. I. Edinburgh: Archibald \& co.

(1820b), History of the Indian Archipelago: Vol. III. Edinburgh: Archibald \& co..

- (1825), "Malay Pirates", Extract from the Singapore Chronicle, republished in The Asiatic Journal and Monthly Register for British India and its Dependencies, 19, pp. 243-5.

(1856), A Descriptive Dictionary of the Indian Islands and Adjacent Countries. London: Bradbury \& Evans.

Keppel, Henry (1853), A Visit to the Indian Archipelago: Vol I. London: Richard Bentley. - (1846), The Expedition to Borneo of H.M.S. Dido for the Suppression of Piracy. New Your Harper \& Brothers. 
Maxwell, Peter Benson (1871), "The destruction of Salangore", The Times (London), 13 September 1871.

- (1878), Our Malay Conquests. Westminster: P. S. King.

Raffles, Sophia. (ed.) (1830), Memoir of the Life and Public Services of Sir Thomas Stamford Raffles. London: John Murray.

Raffles, Thomas Stamford (1817), The History of Java: Vol. I, $1^{\text {st }}$ ed. London: John Murray. - (1830 [1819]), "On the Administration of the Eastern Islands", in Sophia Raffles (ed.), Memoir of the Life and Public Services of Sir Thomas Stamford Raffles. London: John Murray, Appendix, pp. 3-22.

Swettenham, Frank A. (1907), British Malaya. London \& New York: John Lane.

\section{Literature}

Amirell, Stefan Eklöf (2019 [forthcoming]), Pirates of empire: Colonisation and maritime violence in Southeast Asia. Cambridge, UK: Cambridge University Press.

Benton, Lauren \& Lisa Ford (2016), Rage for order: The British Empire and the origins of international law, 1800-1850. Cambridge, MA \& London: Harvard University Press.

Chew, Emrys (2012), Arming the periphery: The arms trade in the Indian Ocean during the age of global empire. Houndmills, Basingstoke: Palgrave Macmillan.

Cowan, Charles Donald (1961), Nineteenth-century Malaya. London: Oxford University Press.

Earle, Peter (2004), The pirate wars. London: Methuen.

Elias, Norbert (1939), Über den Prozess der Zivilisation: Soziogenetische und psychogenetische Untersuchungen. Basel: Haus zum Falken.

Fisch, Jörg (1992), "Zivilisation, Kultur" in Otto Brunner, Werner Conze \& Reinhart Koselleck (eds), Geschichtliche Grundbegriffe: Historisches Lexikon zur politischsozialen Sprache in Deutschland: Band 7. Stuttgart: Klett-Cotta, pp. 679-774.

Gullick, J. M. (1986), 'Tunku Kudin in Selangor (1868-1878)', Journal of the Malaysian Branch of the Royal Asiatic Society, 59:2, pp. 5-50.

-_ (1996), 'The Kuala Langat piracy trial', Journal of the Malaysian Branch of the Royal Asiatic Society 69:2, pp. 101-114.

Kaiser, Wolfgang \& Guillaume Calafat (2014), "Violence, protection and commerce: Corsairing and ars piratica in the early modern Mediterranean", in Stefan Eklöf Amirell \& Leos Müller (eds), Persistent piracy: Maritime violence and state-formation in global historical perspective. Houndmills, Basingstoke: Palgrave Macmillan, pp. 69-92.

Knapman, Gareth (2017), Race and British colonialism in South-East Asia, 1770-1870. New York \& London: Routledge.

Koskenniemi, Martti (2001), The gentle civilizer of nations: The rise and fall of international law 1870-1960. Cambridge: Cambridge University Press.

Layton, Simon (2011), "Discourses of piracy in an age of revolutions", Itinerario 35:2, pp. 81-97.

Lindqvist, Sven (1996 [1992]), Exterminate all the brutes. New York: The New Press.

Koselleck, Reinhart (1985), "The historical-political semantics of ssymmetric counterconcepts", in idem, Futures past: On the semantics of historical time. Cambridge, MA: MIT Press, pp. 159-97.

Makepeace, Walter (1921), "Concerning known persons", in Walter Makepeace, Gilbert E. Brooke \& Roland St J. Braddell (eds), One hundred years of Singapore: Vol. II. London: John Murray.

Mills, Lennox Algernon (1960 [1925]), "British Malaya, 1824-67”, Journal of the Malayan Branch of the Royal Asiatic Society 33:3. 
Osterhammel, Jürgen (2007), "Approaches to global history and the question of the 'civilizing mission"”, Working Paper 2007/3. Osaka: Osaka University, Program on Global History and Maritime Asia.

Parkinson, C. Northcote (1960), British intervention in Malaya 1867-1877. Singapore: Malaya University Press.

Reber, Anne Lindsey (1966), "The Sulu world in the 18th and early 19th centuries". Unpubl. Ph.D. thesis, Cornell University.

Rediker, Marcus (2004), Villains of all nations: Atlantic pirates in the Golden Age. London: Verso.

Reid, Anthony (1993), Southeast Asia in the age of commerce: Volume 2: Expansion and crisis. New Haven: Yale University Press.

Rubin, Alfred. P. (1974), Piracy, paramountcy and protectorates. Kuala Lumpur: Penerbit Universiti Malaya.

- (1998), The law of piracy. Irvington-on-Hudson, N.Y.: Transnational Publishers.

Tarling, Nicholas (1999), "The establishment of the colonial régimes" in idem (ed.), The Cambridge history of Southeast Asia: Volume 2, Part 1. Cambridge, UK: Cambridge University Press.

- (1978 [1963]), Piracy and Politics in the Malay World. Nendeln: Kraus Reprint.

Teitler, Ger., A. M. C. van Dissel \& J. N. F. M à Campo (2005), Zeeroof en zeeroofbestrijding in de Indische archipel (19de eeuw). Amsterdam: De Bataafsche Leeuw.

Trocki, Carl (2012 [1979]), Prince of pirates: The Temenggongs and the development of Johor and Singapore, 1784-1885, $2^{\text {nd }}$ ed. Singapore: NUS Press.

Turnbull, Constance M. (1957), "Governor Blundell and Sir Benson Maxwell”, Journal of the Malayan Branch of the Royal Asiatic Society 30:1.

Walker, John Henry (2002), Power and prowess: The origins of Brooke kingship in Sarawak. Crows Nest, NSW: Allen and Unwin \& Honolulu: University of Hawai'i Press.

Warren, James F. (1981), The Sulu Zone 1768-1898: The dynamics of external trade, slavery and ethnicity in the transformation of a Southeast Asian maritime state. Singapore: Singapore University Press.

-_ (2002), Iranun and Balangingi: Globalization, maritime raiding and the birth of ethnicity. Singapore: Singapore University Press.

Webster, Anthony (1998), Gentlemen capitalists: British imperialism in South East Asia 1770-1890. London \& New York: Tauris Academic Studies.

White, Joshua M. (2018), Piracy and law in the Ottoman Mediterranean. Stanford, CA: Stanford University Press. 